\title{
Budgetary pressures squeeze German research institutes
}

Munich. The Hahn-Meitner Institute in Berlin will abandon its nuclear physics and electronics research activities in one of the first comprehensive responses by a national research centre to demands from the German government to cut costs and increase accountability.

The 16 centres, most of them founded 30 years ago, carry out long-term research beyond the means of a university. In 1991, the former research minister, Heinz Riesenhuber, laid out plans to change a system that the government had long felt was over-staffed, inflexible and lacking in external evaluations. The general financial constraints that have followed reunification and the creation of three new national research centres in the former East Germany have focused attention on the centres, which together receive 70 per cent of the federal government's research budget.

Riesenhuber realigned priorities for the national research centres, which get 90 per cent of their money from the federal government and the rest from the Länder, by lowering federal support and asking them to reduce their work force of 22,000 by 1,800 . But the cuts are not uniform. Areas such as nuclear energy research, politically unattractive in Europe's 'greenest' country, suffered badly while more fashionable areas such as climate research have been better protected. In addition, the operating budgets of most institutes have been frozen at 1992 levels until at least 1995.

The Hahn-Meitner Institute must lose

\section{Staffing levels at national research centres}

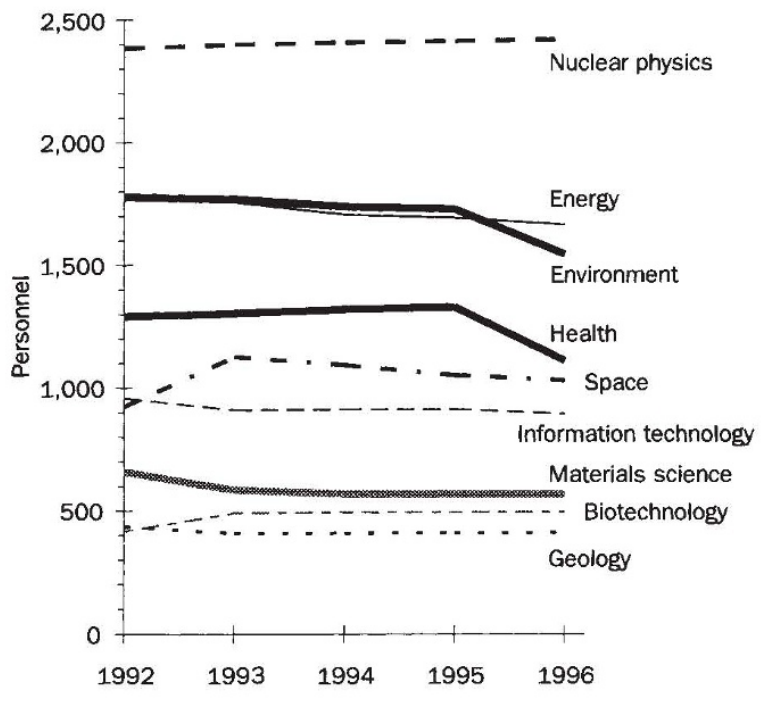

Source: German Ministry of Research at least 50 people - 10 per cent of its permanent staff. Last month, the institute's advisory board decided to use the restructuring to concentrate on solar energy and structures research. Nuclear technology research will be completely wound down by 1995 , after which its heavy-ion accelerator will be used only to treat patients with eye cancer.

Other institutes facing a similar cut of 10 per cent in personnel include the German air and space research centre (DLR), the biotechnology research centre (GBF), the environment and health research centre (GSF) and the institute for plasma physics (IPP). Each hopes to avoid forced redundancies, which follow 10 years of smaller cuts that have chipped away at their missions, and none has specific plans to change research priorities. "We are now having to eat into our own flesh", says Richard Radlof of the GBF, which is losing 30 full-time positions.

Thomas Köstlin, head of administration at the plasma physics institute, says that staff has been trimmed each year since 1980. Some positions were returned, however, and the exercise served to circulate scientists between research establishments. "But since we only have one topic", he says, "it is more difficult for us to receive people back." The institute must now lose 96 - about a tenth - of its present staff, and the cuts mean that the start of construction of a Wendelstein $7 \mathrm{X}$ accelerator will be delayed until at least 1995 .

But the biggest blow falls on the four centres whose areas of research are deemed to be no longer interesting. By the end of this year, the society for exploration of nuclear energy in shipping will lose its underwater technology department, which was developed 15 years ago on the faulty assumption that German industry would require such expertise.

The GMD, the centre for mathematics and data handling near Bonn, is to lose 100 of its staff of 1,300 . In addition, its budget has been cut drastically following the failure of an important cooperative project with industry relating to parallel computing, and the centre is shifting resources into applied research.

The two largest national research centres, $\mathrm{KfK}$ and KFA, each with more than

\section{IMAGE UNAVAILABLE FOR COPYRIGHT REASONS}

\section{Hahn-Meitner's heavy-ion accelerator will soon cease being a research tool.}

4,000 staff, are under the greatest pressure to abandon their original mandate to foster nuclear technology. With budgets that have been squeezed hard for the past decade, they have been ordered to lose up to 20 per cent of their staff in the next three years and to find worthwhile projects that do not involve non-safety aspects of nuclear technology research. Concerned about what may happen if they do not demonstrate greater accountability, they nevertheless face the difficult job of retraining scientists whose raison d'être had been a single research project.

The new smaller national research centres hope that a new management approach giving them greater flexibility will help them to survive the current economic crisis. Such a system would replace the current system of evaluations, which the research ministry believes do not provide sufficient accountability. Alison Abbott

\section{OTA tackles gene patents}

Washington. A panel of legal experts met last week at the congressional Office of Technology Assessment (OTA) to mull over the legal implications of patenting human DNA sequences. Although the one-day meeting raised more questions than it answered, panel members felt that the challenge for such applications is meeting the legal standards of 'utility' and 'nonobviousness'.

One of the most troubling questions raised at the meeting was the effect of granting patent rights for partial human DNA sequences on patents for full-length genes whose biological function has been elucidated. It is feared that companies prevented from making such patent claims would be reluctant to invest in research in this area.

OTA will evaluate the commercial, ethical, legal and social implications of patenting human DNA sequences in the wake of a 1991 filing by the National Institutes of Health for patents on thousands of human DNA sequences of uncharacterized function. In July it will consider the effect of such actions on international research. Its report is due next spring. Diane Gershon 